\title{
Short Circuit Analysis on Distribution Network 20 kV Using Etap Software
}

\author{
Afif Arizaldi ${ }^{\bowtie 1}$, Salahuddin ${ }^{1}$, Muhammad$^{1}$, Vishal Jain², Govinda Prashad Pandey ${ }^{3}$, \& Manoj Jagannathrao Watane ${ }^{4,5}$, \\ ${ }^{1}$ Department of Electrical Engineering, Malikussaleh University, Bukit Indah, Lhokseumawe, 24355, Indonesia. \\ ${ }^{2}$ Sharda University, Greater Noida, India \\ ${ }^{3}$ Tribhuvan University, Nepal \\ ${ }^{4}$ Dr. Sau. Kamaltai Gawai Institute of Engineering and Technology, Darapur, Dist. Amravati, Maharashtra, India, 444814 \\ ${ }^{5}$ Sant Gadge Baba Amravati University, Amravati, Maharashtra, India, 444702 \\ afifarizaldi00@gmail.com; salahuddin@unimal.ac.id; muhammad@unimal.ac.id; drvishaljain83@gmail.com; pandasuppy91@gmail.com \\ manoj.watane25@gmail.com \\ ${ }^{\bowtie}$ Corresponding Author: afifarizaldi00@gmail.com | Phone: +6285270508744
}

Received: September 8, 2021

Revision: September 18, 2021

Accepted: September 30, 2021

\begin{abstract}
In an electric power system, electricity is generated by the power plant and then channeled to a transmission line and then distributed to consumers, in the process of distributing electrical energy, the system does not always work in normal conditions, sometimes the system can experience disturbances such as one-phase, two-phase, and three-phase disturbances. This interference can disrupt the electrical system and can damage equipment if left unchecked, therefore it is necessary to install a protection device that can decide the interference so as not to damage other equipment when a disturbance occurs. Here the protection device used is a circuit breaker. In a fault condition, the circuit breaker must be able to separate the points of the fault so as not to damage other electrical equipment. In this case, to determine the capacity of the best protection device for the system, a short circuit fault simulation is performed. To simplify the calculation process here the author uses the help of ETAP software (Electrical Transient Analysis Program).
\end{abstract}

Keywords: short circuit fault; circuit breaker; ETAP (Electrical Transient Analysis Program);

\section{Introduction}

In a broad electric power system, sometimes disturbances that come from outside cannot be avoided, therefore it is necessary to conduct an analysis of the electric power system to assist in planning and analyzing the system in order to create a system that is able to work optimally.[1].

In this paper the author will try to determine the safety capacity that is able to protect the electrical system and is able to work well in the city electrical system of Lhokseumawe, using the help of ETAP software in conducting case studies and calculations of short circuit disturbances.

\section{Literature Review}

Single Phase Short Circuit to Ground

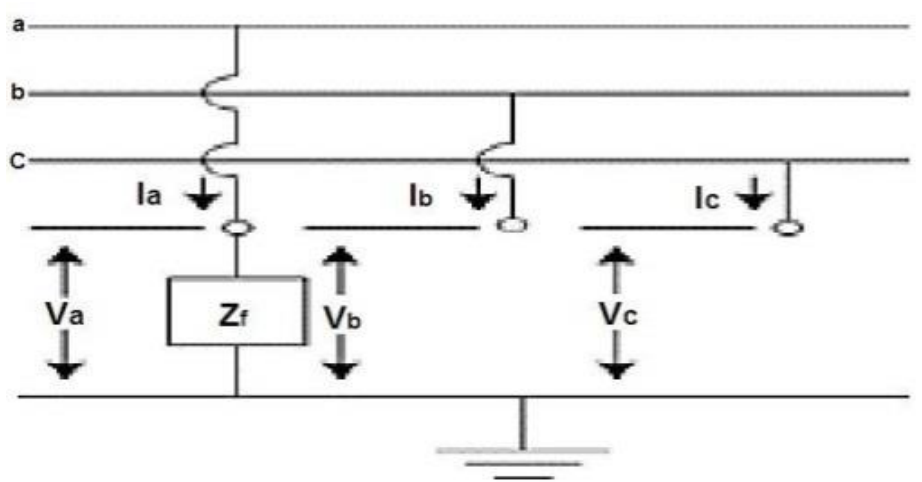

Figure 1. Single Phase Short Circuit to Ground [2] 
Figure 1 is an illustration of the form of short circuit fault that occurs due to phase and ground connection, is a short circuit fault that often occurs in electric power distribution systems. To calculate the magnitude of the one-phase fault current to ground, you can use the equation[3]:

$$
\mathrm{I}_{\mathrm{hs}-1 \varnothing}=\frac{3 V f}{Z 1+Z 2+Z 0}
$$

\section{Two Phase to Ground Fault}

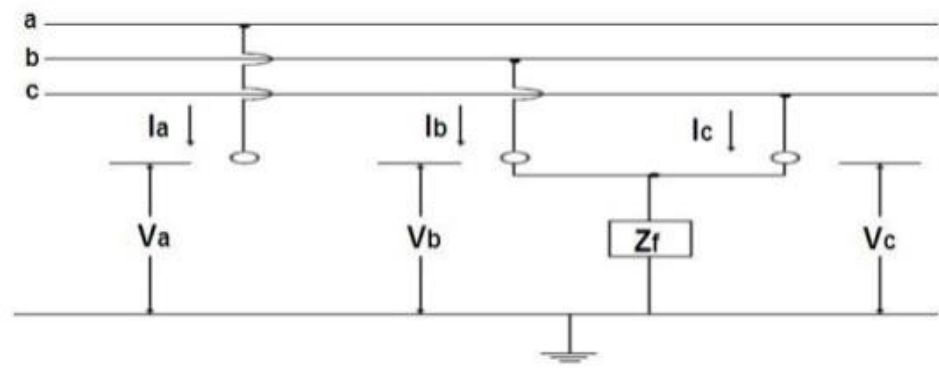

Figure 2. Two phase to ground fault [4]

Two phase to ground fault is a short circuit that occurs because two feeders or conductors are connected to the ground, is an asymmetrical short circuit with a fault incidence percentage of $10 \%$. To determine the amount of short circuit two-phase ground fault current can be calculated by the formula[5]:

$$
\mathrm{I}_{\mathrm{hs}-2 \varnothing}=\frac{V f}{Z 1+Z 2(Z 0+3 Z f) /(Z 2+Z 0+3 Z f)}
$$

\section{Line-to-Line Fault}
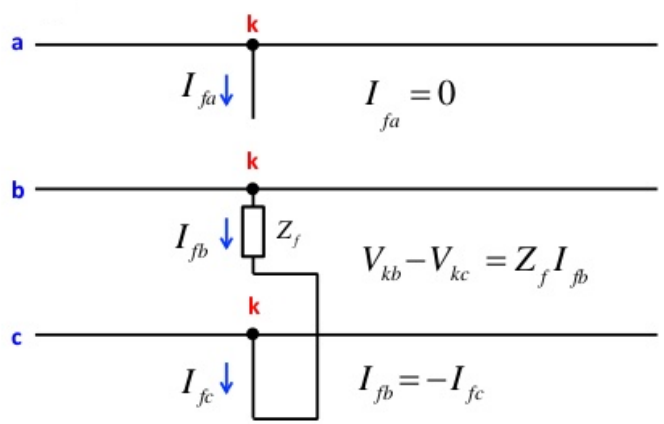

Figure 3. Line-to-Line Fault

Short circuit between phases is a short circuit that occurs because it is connected between two phases, is an asymmetrical short circuit fault with a percentage of the incidence of $15 \%$. To determine the amount of short circuit fault current between phases can be calculated by the formula[6]:

$$
\mathrm{I}_{\mathrm{hs}-2 \varnothing}=\frac{V f}{Z 1+Z 2+Z f}
$$

\section{Three Phase Short Circuit}

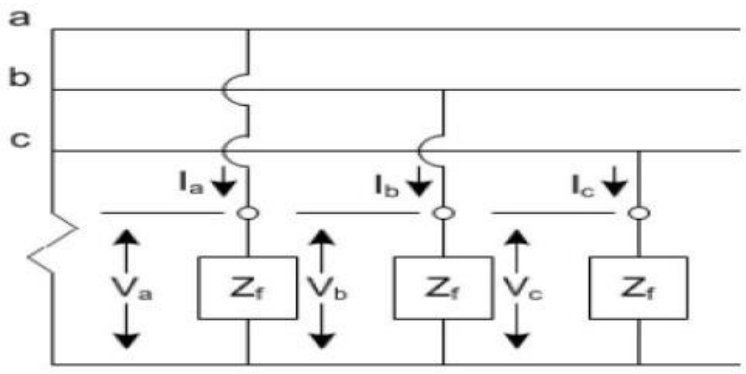

Figure 4. Three phase short circuit 
Three-phase short circuit as in Figure 2. occurs when the three phases are connected, this fault is a rare disturbance compared to the presentation of single and two-phase short circuit events with an incidence percentage of $5 \%$, is a symmetrical disorder. To calculate the large three-phase short circuit fault current can be calculated by the equation[7]:

$$
\mathrm{I}_{\mathrm{hs}-3 \varnothing}=\left|\frac{V f}{Z 1}\right|
$$

\section{Materials \& Methods}

\section{Tools and materials}

In this study, several supporting equipment were used, including: Laptop with N2840 processor model specifications, $500 \mathrm{~Gb}$ HDD, 2 Gb RAM. Windows operating system 10.ETAP software 16.

The materials used in this study were data collection of $20 \mathrm{KV}$ medium voltage distribution system at LancangGaram (GH) substation, Darussalam feeder (Lhokseumawe City). These data, among others:

a. Power data on GH Lancang Garam

Table 1. Power data on GH lancanggaram

\begin{tabular}{clcc}
\hline No & & Description & Unit \\
\hline 1 & Maximum Power & 59.98 & MVA \\
2 & Voltage & 20 & KV \\
3 & Frequency & 50 & Hertz \\
4 & Power Factor & 80 & Persen \\
\hline
\end{tabular}

b. 3 Phase transformer data

Table 2. Transformer data

No No.Substation $\quad$ Substation address $\quad$ Power (KVA) $\quad \begin{gathered}\text { Phase } \\ \text { Impedance } \\ (\%)\end{gathered} \quad \begin{gathered}\text { Power Consumed } \\ (\text { KVA })\end{gathered}$

\begin{tabular}{|c|c|c|c|c|c|c|}
\hline 1 & BS 202 & Gg. Materna & 100 & 3 & 4 & 4.24 \\
\hline 2 & BS 203 & AsramaPerwira & 100 & 3 & 4 & 26.62 \\
\hline 3 & BS 189 & Masjid Baiturrahman & 160 & 3 & 4 & 62.4 \\
\hline 4 & BS 221 & Baiturrahman II & 100 & 3 & 4 & 38.23 \\
\hline 5 & BS 154 & Sp. TpTeurendam & 100 & 3 & 4 & 66.61 \\
\hline 6 & BS 146 & RsBunda & 160 & 3 & 4 & 83.2 \\
\hline 7 & BS 071 & Sp. Malikussaleh & 200 & 3 & 4 & 135.79 \\
\hline 8 & BS 103 & Gg. Setia & 200 & 3 & 4 & 100.31 \\
\hline 9 & BS 003 & GG. Damai & 250 & 3 & 4 & 164.47 \\
\hline 10 & BS 204 & Dpn. Sam Brother & 100 & 3 & 4 & 49 \\
\hline 11 & BS 112 & Dpn SMA-1 & 100 & 3 & 4 & 42.26 \\
\hline 12 & BS 145 & Dpn SMA-1 (3) & 50 & 3 & 4 & 30.79 \\
\hline 13 & BS 053 & Dpn SMA-1 & 100 & 3 & 4 & 47.04 \\
\hline 14 & BS 198 & Gg. Amal Darussalam & 100 & 3 & 4 & 44.99 \\
\hline 15 & BS 092 & DpnPrm. BI & 100 & 3 & 4 & 56.44 \\
\hline 16 & BS 147 & BaksoPakde & 50 & 3 & 4 & 39.08 \\
\hline 17 & BS 016 & PLTD Hagu & 200 & 3 & 4 & 78.32 \\
\hline 18 & BS 168 & PLTD Hagu (II) & 160 & 3 & 4 & 61.36 \\
\hline
\end{tabular}


c. Channel or conductor data

Table 3. Conductor data

\begin{tabular}{|c|c|c|c|c|c|}
\hline No & From Bus & To Bus & Long $(\mathrm{m})$ & Type of conductor and cross-sectional area & Circuit \\
\hline 1 & GH & BS 202 & 60 & XLPE $3 X 240 \mathrm{~mm}^{\wedge} 2$ & 1 \\
\hline 2 & BS 202 & BS 203 & 260 & AAAC $3 \times 150 \mathrm{~mm}^{\wedge} 2$ & 1 \\
\hline 3 & BS 203 & BS 146 & 100 & AAAC $3 \times 150 \mathrm{~mm}^{\wedge} 2$ & 1 \\
\hline 4 & BS 146 & BS 154 & 300 & AAAC $3 \times 150 \mathrm{~mm}^{\wedge} 2$ & 1 \\
\hline 5 & BS 154 & BS 221 & 160 & AAAC $3 \times 150 \mathrm{~mm}^{\wedge} 2$ & 1 \\
\hline 6 & BS 221 & BS 189 & 50 & AAAC $3 \times 150 \mathrm{~mm}^{\wedge} 2$ & 1 \\
\hline 7 & BS 203 & BS 071 & 60 & AAAC $3 \times 150 \mathrm{~mm}^{\wedge} 2$ & 1 \\
\hline 8 & BS 071 & BS 103 & 170 & AAAC $3 \times 150 \mathrm{~mm}^{\wedge} 2$ & 1 \\
\hline 9 & BS 103 & BS 003 & 120 & AAAC $3 \times 150 \mathrm{~mm}^{\wedge} 2$ & 1 \\
\hline 10 & BS 003 & BS 204 & 100 & AAAC $3 \times 150 \mathrm{~mm}^{\wedge} 2$ & 1 \\
\hline 11 & BS 204 & BS 112 & 100 & AAAC $3 \times 150 \mathrm{~mm}^{\wedge} 2$ & 1 \\
\hline 12 & BS 112 & BS 145 & 100 & AAAC $3 \times 150 \mathrm{~mm}^{\wedge} 2$ & 1 \\
\hline 13 & BS 145 & BS 053 & 50 & AAAC $3 \times 150 \mathrm{~mm}^{\wedge} 2$ & 1 \\
\hline 14 & BS 053 & BS 198 & 220 & AAAC $3 \times 150 \mathrm{~mm}^{\wedge} 2$ & 1 \\
\hline 15 & BS 198 & BS 092 & 100 & AAAC $3 \times 150 \mathrm{~mm}^{\wedge} 2$ & 1 \\
\hline 16 & BS 092 & BS 147 & 100 & AAAC $3 \times 150 \mathrm{~mm}^{\wedge} 2$ & 1 \\
\hline 17 & BS 147 & BS 016 & 130 & AAAC $3 \times 150 \mathrm{~mm}^{\wedge} 2$ & 1 \\
\hline 18 & BS 016 & BS 168 & 50 & AAAC $3 X 150 \mathrm{~mm}^{\wedge} 2$ & 1 \\
\hline
\end{tabular}

d. Image of a single line diagram of a $20 \mathrm{KV}$ medium voltage distribution system

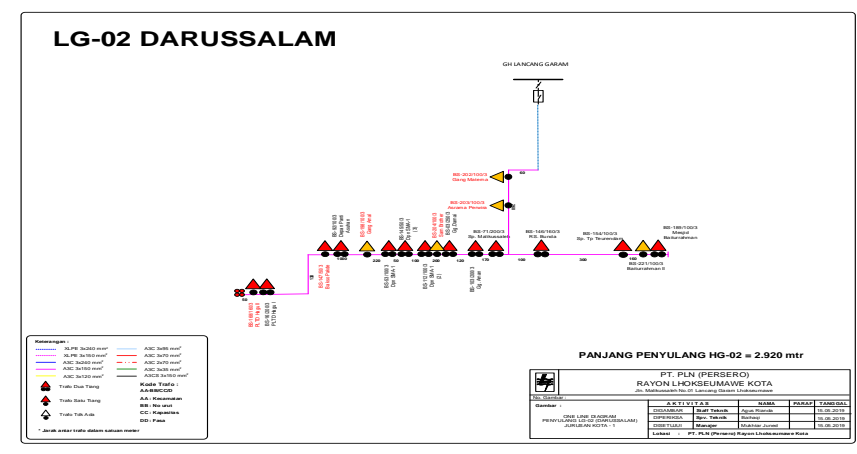

Figure 5. Single line diagram of a medium voltage distribution system

\section{Research Steps}

The research begins with a literature study on related studies as a theoretical basis for conducting this research. Furthermore, data collection is carried out and taken directly at PT. PLN (Persero) ULP Lhokseumawe City. The data taken is one line diagram data, source data, distribution transformer data, and complete load data can be seen in Figure 3.1 flow diagram. 


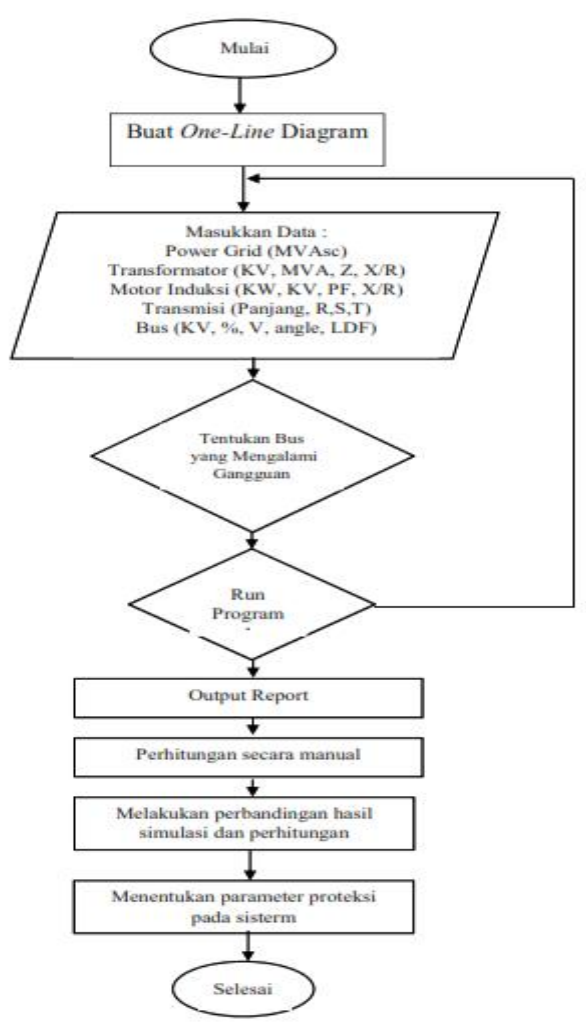

Figure 6. Flow chart.

\section{Results and Discussion}

\section{Study of Short Circuit Interference on 20 kV Distribution Network}

A reliable system is a system that is not only able to work in normal conditions but is also able to solve problems when conditions are not normal so that the resulting impact does not damage other equipment, therefore short circuit fault analysis is very helpful to determine good protection settings for the system.

\section{Short Circuit Interference Analysis}

The calculation of the short circuit fault current that occurs on the GH bus is as follows:

Positive and Negative sequence source impedance calculations

$$
\begin{aligned}
\mathrm{X}_{1 \mathrm{~s}}=\quad \mathrm{X}_{2 \mathrm{~s}} & =0+\mathrm{J} \frac{(K V)^{2}}{M V A_{H S-3 \emptyset}} \\
& =0+\mathrm{J} \frac{(20)^{2}}{59.98} \\
& =0+\mathrm{J} 0.0066 \\
& =\mathrm{J} 6.6
\end{aligned}
$$

Zero sequence source impedance calculation

$$
\begin{aligned}
\mathrm{X}_{0 \mathrm{~s}} & =\mathrm{J} \frac{3(K V)^{2}}{M V A_{S-1 \varnothing}} \\
& =\mathrm{J} \frac{3(20)^{2}}{22.5 M V A} \\
& =\mathrm{J} \frac{1200}{22.5 X 10^{3}} \\
& =\mathrm{J} 0.0533 \\
& =\mathrm{J} 53.4
\end{aligned}
$$

The impedance of the positive and negative sequence transformers

$$
\begin{aligned}
\mathrm{X}_{1 \mathrm{~T}}=\quad \mathrm{X}_{2 \mathrm{~T}} & =\mathrm{Jz}_{1} \times \frac{(K d)^{2}}{S d} \\
& =\mathrm{J} 0.04 \times \mathrm{J} \frac{(20)^{2}}{100 K V A} \\
& =\mathrm{J} 0.04 \times 4
\end{aligned}
$$


$=\mathrm{J} 0.16$

Zero Sequence Transformer Impedance

$$
\begin{array}{ll}
\mathrm{X}_{0 \mathrm{~T}} & =10 \times \mathrm{X}_{1 \mathrm{~T}} \\
& =10 \times \mathrm{J} 0.16 \\
& =\mathrm{J} 16 \\
3 \times \mathrm{R}_{\mathrm{n}} & =3 \times 40 \Omega=120 \Omega \\
\mathrm{X}_{0 \mathrm{~T}} & =120+\mathrm{J} 16
\end{array}
$$

Feed impedance calculation

For feeders on the GH bus using an XLPE conductor with a cross-sectional area of $240 \mathrm{~mm} 2$ based on SPLN 64: 1985 it is known that the channel impedance $(Z)$ value:

$$
\begin{aligned}
& \mathrm{Z}_{1} / \mathrm{Km}=0.1344+\mathrm{J} 0.3158 \\
& \mathrm{Z}_{2} / \mathrm{Km}=0.1344+\mathrm{J} 0.3158 \\
& \mathrm{Z}_{0} / \mathrm{Km}=0.2824+\mathrm{J} 1.6034
\end{aligned}
$$

The distance of the GH bus to bus 202 is 60 meters or $0.06 \mathrm{Km}$ so that by multiplying the length of the feeder (km) and the impedance of the conductor $(Z)$, the impedance value is as follows:

$$
\begin{array}{ll}
\mathrm{Z}_{1} & =0.008+\mathrm{J} 0.019 \\
\mathrm{Z}_{2} & =0.008+\mathrm{J} 0.019 \\
\mathrm{Z}_{0} & =0.017+\mathrm{J} 0.096
\end{array}
$$

The location of the disturbance

$$
\begin{aligned}
\mathrm{Z}_{1} \mathrm{l}(\%) & =0.008 \%+\mathrm{J} 0.019 \% \\
& =8 \times 10^{-5}+\mathrm{J} 19 \times 10^{-5} \\
\mathrm{Z}_{0} \mathrm{l}(\%) & =0.017 \%+\mathrm{J} 0.096 \% \\
& =17 \times 10^{-5}+\mathrm{J} 96 \times 10^{-5}
\end{aligned}
$$

Positive and negative sequence impedance

$$
\begin{aligned}
Z_{1}=Z_{2} & =Z_{1 s}+Z_{1 \mathrm{~T}}+Z_{1 L}(1 \%) \\
& =J 6.6+J 0.16+8 \times 10^{-5}+19 \times 10^{-5} \\
& =8 \times 10^{-5}+\mathrm{J} 6.7 \\
& =6.7 \angle 83.7
\end{aligned}
$$

Zero sequence impedance

$$
\begin{aligned}
Z_{0} & =Z_{0 s}+Z_{0 \mathrm{~T}}+Z_{0 \mathrm{~L}} \\
& =\mathrm{J} 53.4+120+\mathrm{J} 16+17 \times 10^{-5}+\mathrm{J} 96 \times 10^{-5} \\
& =120.00017+\mathrm{J} 69.4 \\
& =138.62 \angle 30.11
\end{aligned}
$$

Calculates the three-phase fault current

$$
\begin{aligned}
\mathrm{I}_{\mathrm{hs}-3 \varnothing} & =\left|\frac{V f}{\mathrm{Z} 1}\right| \\
& =\frac{20 K V / \sqrt{3}}{6.7 \angle 83.7} \\
& =\frac{11547}{67 \angle 83.7} \\
& =1723.5 \angle-83.7 \mathrm{~A} \\
& =1.723 \mathrm{KA}
\end{aligned}
$$

Calculates the two-phase ground fault current

$$
\begin{gathered}
\mathrm{I}_{\mathrm{hs}-2 \varnothing=\mid} 0.866 \times 1723.5 \mid \\
=1492.6 \mathrm{~A} \\
=1.5 \mathrm{KA}
\end{gathered}
$$

Calculates phase-to-phase fault current

$$
\mathrm{I}_{\mathrm{hsø- \varnothing}}=|0.918 \times 1723.5|
$$




$$
\begin{aligned}
& =1582.18 \mathrm{~A} \\
& =1.582 \mathrm{KA}
\end{aligned}
$$

Calculates the single-phase fault current

$$
\begin{aligned}
\mathrm{I}_{\mathrm{hs}-1 \varnothing} & =\frac{3 V f}{\mathrm{Z} 1+\mathrm{Z} 2+\mathrm{Z} 0} \\
& =\frac{3 \times 11547}{2 \times\left(8 \times 10^{-5}+\mathrm{J} 6.7\right)+120.00017+\mathrm{J} 69.4} \\
& =\frac{34641}{0.00016+\mathrm{J} 13.4+120.00017+\mathrm{J} 69.4} \\
& =\frac{34641}{120.00033+\mathrm{J} 82.8} \\
& =\frac{34641}{120.00033+\mathrm{J} 82.8} \times \frac{120.00033-\mathrm{J} 82.8}{120.00033-\mathrm{J} 82.8} \\
& =\frac{4156931.5-\mathrm{J} 2868274.8}{7544.24} \\
& =551.007-\mathrm{J} 380.2 \\
& =669.45 \angle-34.6 \mathrm{~A} \\
& =0.669 \mathrm{KA}
\end{aligned}
$$

From the above calculations, it is obtained that the three-phase fault current is $1,723 \mathrm{KA}$, the two phase to ground fault is $1.5 \mathrm{KA}$, the inter-phase fault current is $1,582 \mathrm{KA}$ and the single-phase fault current is $0.669 \mathrm{KA}$.

\section{Short Circuit Interference Analysis Using ETAP Software}

\begin{tabular}{|c|c|c|c|c|c|c|c|c|c|}
\hline \multirow[b]{2}{*}{ Bus ID } & \multirow[b]{2}{*}{ KV } & \multicolumn{4}{|c|}{ Simulation Results } & \multicolumn{4}{|c|}{ The calculation results } \\
\hline & & $\begin{array}{l}\text { Three-phase } \\
\text { fault current } \\
\text { (KA) }\end{array}$ & $\begin{array}{l}\text { Two-phase } \\
\text { fault current } \\
\text { to ground } \\
\text { (KA) }\end{array}$ & $\begin{array}{l}\text { Inter- } \\
\text { phase } \\
\text { fault } \\
\text { current } \\
\text { (KA) }\end{array}$ & $\begin{array}{c}\text { Single } \\
\text { Phase } \\
\text { Interferen } \\
\text { ce Current } \\
\text { (KA) }\end{array}$ & $\begin{array}{l}\text { Three- } \\
\text { phase } \\
\text { fault } \\
\text { current } \\
\text { (KA) }\end{array}$ & $\begin{array}{l}\text { Two-phase } \\
\text { fault current } \\
\text { to ground } \\
\text { (KA) }\end{array}$ & $\begin{array}{l}\text { Inter- } \\
\text { phase } \\
\text { fault } \\
\text { current } \\
\text { (KA) }\end{array}$ & $\begin{array}{c}\text { Single Phase } \\
\text { Interference } \\
\text { Current } \\
\text { (KA) }\end{array}$ \\
\hline $\begin{array}{l}\text { Bus } \\
\text { GH }\end{array}$ & 20 & 1.828 & 1.599 & 1.583 & 0.658 & 1.723 & 1.5 & 1.582 & 0.669 \\
\hline
\end{tabular}

From the calculation of short circuit fault with ETAP software, the following results are obtained :

Table 4. The magnitude of the short circuit fault current

\begin{tabular}{cccccc}
\hline Bus ID & KV & $\begin{array}{c}\text { Three-phase fault current } \\
\text { (KA) }\end{array}$ & $\begin{array}{c}\text { Two-phase fault current to } \\
\text { ground (KA) }\end{array}$ & $\begin{array}{c}\text { Inter-phase fault } \\
\text { current (KA) }\end{array}$ & $\begin{array}{c}\text { Single phase fault } \\
\text { current (KA) }\end{array}$ \\
\hline Bus GH & 20 & 1.828 & 1.599 & 1.583 & 0.658 \\
\hline
\end{tabular}

The highest fault current occurs at a three-phase fault current of 1,828 KA and the lowest fault current occurs at a single-phase fault current of $0.658 \mathrm{KA}$

\section{Comparison of Simulation Results and Manual Calculations for Short Circuit Fault Analysis}

The short circuit fault current generated by manual calculation using the formula is compared with calculations using the Etap simulation to determine the level of accuracy. The following is a comparison of the results of the two in the table 5 .

Table 5. Comparison of simulation results and manual calculations

From table 5 the difference between simulation results and calculation results from three-phase, two-phase and one-phase faults is only a little, this proves the level of accuracy of this Etap software is very good in analyzing short circuit faults. 


\section{Determination of Disconnect Capacity and Overcurrent Relay Settings}

The capacity of the power breaker is the highest amount of noise current multiplied by a safety factor of $125 \%$ according to the general requirements for electrical installations (PUIL) [8]. The following is the calculation of the breaker capacity

Circuit-breaker capacity for GH Bus protection

$$
\begin{aligned}
\text { Icb } & =\text { Ihs } 3 \varnothing \times 125 \% \\
& =1.828 \times 1.25 \\
& =2.285 \mathrm{KA}
\end{aligned}
$$

OCR overcurrent relay setting calculation

Diketahui : KVA $=1169$ KVA

Rasio CT $=1: 300$

Isc Max $=1828 \mathrm{~A}$

Isc $\mathrm{Min}=658 \mathrm{~A}$

1. Calculate FLA (Full Load Amper)

$$
\begin{aligned}
\text { FLA } & =\frac{K V A}{\sqrt{3 x} K V} \\
& =\frac{1169}{\sqrt{3 x} 20} \\
=33,7 \mathrm{~A} &
\end{aligned}
$$

2. Current Pick UP

$$
\begin{aligned}
\text { Ipick up } & =\frac{1.1 \times F L A}{\text { Rasio } C T} \\
& =\frac{1.1 \times 33.7}{300} \\
& =0.12 \mathrm{~A}
\end{aligned}
$$

3. Is

$$
\begin{aligned}
\text { Is = Ipick } & \text { up } \times \text { Rasio CT } \\
= & 0.12 \times 300 \\
= & 36 \mathrm{~A}
\end{aligned}
$$

4. Time Multiplier Setting (TMS)

TMS

$$
\begin{aligned}
& =\frac{T x\left(\frac{(I s c \text { Max })^{0.02}-1}{I s}\right)}{0.14} \\
& =\frac{0.04}{0.14} \\
& =0.28 \mathrm{~s}
\end{aligned}
$$

5. Current Pick Up Instantaneous (Ip)

$$
\begin{aligned}
\text { Ip } & =\frac{0.8 \times \text { Isc } \text { Min }}{\text { Rasio } C T} \\
& =\frac{0.8 \times 658}{300} \\
& =1.75 \mathrm{~A}
\end{aligned}
$$

So that the circuit breaker fault current capacity is obtained is $2.285 \mathrm{KA}$, with a ct ratio of 1 : 300 , Ipick up current $0.12 \mathrm{~A}$ and instant Ipick up current $1.75 \mathrm{~A}$.

\section{Conclusions}

Based on the results of simulation experiments on short circuit fault studies on the 20kV distribution network of PT. PLN (Persero) Feeder Substation Kota Lhokseumawe Darussalam (GH) Lancang Garam obtained the results of short circuit disturbances that occur on the GH bus using Etap software and calculations of 1,828 and 1,723 with a difference of $0.105 \mathrm{KA}$ for three-phase disturbances, then 1.599 and 1.5 with difference of 0.099 for two-phase ground fault, 1.583 and 1.582 with a difference of 0.001 for inter-phase faults, 0.658 and 0.669 with a difference of 0.011 for single-phase earth faults so that the capacity of the circuit breaker to secure the LG-02 Darussalam electrical system is 2.285 KA with overcurrent relay settings as follows: ct ratio 1: 300 , current pick up $0.12 \mathrm{~A}$ and pick-up instantaneous at $1.75 \mathrm{~A}$. 


\section{Acknowledgments}

In writing this journal the writer gets a lot of help and support from various parties. Therefore, the authors would like to thank mothers and fathers who always pray for and encourage the author, to Mr. ArnawanHasibuan ST., MT and Mr. Salahuddin ST., MT who have guided and provided input for me, to friends and all parties. which has encouraged the author to complete this research.

\section{References}

[1] A. Hasibuan, S. Masri, and W. Othman, "Effect of distributed generation installation on power loss using genetic algorithm method," in IOP Conference Series: Materials Science and Engineering, 2018, vol. 308, no. 1, p. 12034.

[2] Hendriyadi, "Perhitungan Arus Gangguan Hubung Singkat Pada Jaringan Distribusi Di Kota Pontianak," J. Tek. Elektro Univ. Tanjungpura, 2017.

[3] F. Hermanto and T. Sukmadi, “Analisis Jatuh Tegangan Dan Arus Hubung Singkat Pada Jaringan Tegangan Menengah Pt Rum," Transient, 2013.

[4] A. Ridgway, "Short circuit," New Sci., 2015, doi: 10.1016/S0262-4079(15)31468-8.

[5] J. Schlabbach, Short-circuit currents. 2005.

[6] C. Prévé, Protection of Electrical Networks. London, UK: ISTE, 2006.

[7] A. R. A. El-Keib, "Power system analysis: short-circuit load flow and harmonics," IEEE Power Eng. Rev., 2002, doi: 10.1109/mper.2002.1098043.

[8] Badan Standardisasi Nasional, Persyaratan Umum Instalasi Listrik 2011 (PUIL 2011). 2011. 